\title{
Effects of TONS504-photodynamic therapy on mouse mammary tumor cells
}

\author{
TOMOHIRO OSAKI $^{1}$, ISAO SAKATA ${ }^{2}$, YOSHIHIRO UTO ${ }^{3}$, MASAMICHI YAMASHITA $^{1}$, YUSUKE MURAHATA ${ }^{1}$, \\ KAZUO AZUMA ${ }^{1}$, TAKESHI TSUKA ${ }^{1}$, NORIHIKO ITO ${ }^{1}$, TOMOHIRO IMAGAWA ${ }^{1}$ and YOSHIHARU OKAMOTO ${ }^{1}$ \\ ${ }^{1}$ Joint Department of Veterinary Clinical Medicine, Faculty of Agriculture, Tottori University, Tottori 680-8553; \\ ${ }^{2}$ Porphyrin Laboratory, Okayama 700-0086; ${ }^{3}$ Department of Bioengineering, Graduate School of Technology, \\ Industrial and Social Sciences, Tokushima University, Tokushima 770-8506, Japan
}

Received December 17, 2017; Accepted April 30, 2018

DOI: $10.3892 / \mathrm{ol} .2018 .8887$

\begin{abstract}
In the present study, TONS504 $\left(\mathrm{C}_{51} \mathrm{H}_{58} \mathrm{~N}_{8} \mathrm{O}_{5} \mathrm{I}_{2}\right.$; molecular weight, 1,116.9), a novel cationic hydrophilic photosensitizer, was synthesized from protoporphyrin IX dimethyl ester through a five-step process according to a patented method for use in photodynamic therapy (PDT). The subcellular localization of TONS504 and the cytotoxic effects of TONS504-mediated PDT in the mouse mammary tumor EMT6 cell line were investigated. TONS504 was localized primarily in the lysosomes and partially in the mitochondria. The cytotoxic effects of TONS504-mediated PDT in the mouse mammary tumor EMT6 cell line were investigated using a WST8 assay and an Oxidative Stress kit. The cell viability values following treatment with $10 \mu \mathrm{g} / \mathrm{ml}$ TONS504 at light energies of $0,1,5$ and $10 \mathrm{~J} / \mathrm{cm}^{2}$ were $92.5,101.8,27.7$ and $1.8 \%$, respectively. The percentages of reactive oxygen species $(\mathrm{ROS})(+)$ cells following the same treatment were 8.6, 8.5, 29.2 and $70.1 \%$, respectively, whereas the percentages of apoptotic cells were 7.1, 5.6, 24.8 and $48.7 \%$, respectively. The percentages of $\mathrm{ROS}(+)$ and apoptotic cells in the group subjected to TONS504-mediated PDT increased in a manner dependent on the TONS504 concentration and light energy. Further studies are required to evaluate the in vivo pharmacokinetics, tissue distribution and photodynamic effects of TONS504.
\end{abstract}

\section{Introduction}

Mammary tumors remain the most common cancer and one of the most fatal diseases in females globally, accounting for $14 \%$ of the total cancer mortalities in 2018 (1-3). With improved breast screening procedures, mammary tumors can

Correspondence to: Professor Tomohiro Osaki, Joint Department of Veterinary Clinical Medicine, Faculty of Agriculture, Tottori University, 4-101 Koyama-Minami, Tottori 680-8553, Japan

E-mail: tosaki@muses.tottori-u.ac.jp

Key words: apoptosis, mammary tumor, photodynamic therapy, TONS504, reactive oxygen species be diagnosed at an early stage. Consequently, less extensive treatment may be required (3).

Photodynamic therapy (PDT) is a minimally invasive cancer treatment. The key agent used in PDT is a photosensitizer, which is a compound that is excited by light and is converted to a triplet-excited state $(4,5)$. Osaki et al, Takahashi et al and Sakata et al developed three novel photosensitizers, TONS501Na (6), TONS501 (7), and TONS504 (6-8). TONS501Na $\left(\mathrm{C}_{37} \mathrm{H}_{38} \mathrm{~N}_{4} \mathrm{Na}_{2} \mathrm{O}_{7}\right.$; molecular weight, 696.8) is a hydrophilic and anionic porphyrin salt, and is a chlorin derivative that can be synthesized from the protoporphyrin IX dimethyl ester via a four-step process (8). In a previous study, TONS501Na-mediated PDT induced the death of mouse mammary tumor EMT6 cells in a concentration-dependent manner; however, dark cytotoxicity was also observed with TONS501Na (6). Therefore, photosensitizers that are ideal for PDT against tumors are required.

TONS504 (Fig. 1) is a novel cationic hydrophilic photosensitizer $\left(\mathrm{C}_{51} \mathrm{H}_{58} \mathrm{~N}_{8} \mathrm{O}_{5} \mathrm{I}_{2}\right.$; molecular weight, 1,116.9) that is synthesized from protoporphyrin IX dimethyl ester via a five-step process $(9,10)$. PDT mediated by TONS504 ointment was reported to produce potent antitumor effects in mouse skin papilloma in an in vivo study (7).

To the best of our knowledge, the effectiveness of TONS504-mediated PDT has not been previously reported in an in vitro study. In the present study, the subcellular localization of TONS504 and the cytotoxic effects of TONS504-mediated PDT in EMT6 cells were investigated.

\section{Materials and methods}

Cell line and culture conditions. Mouse mammary tumor EMT6 cells were supplied by Dr Shinichiro Masunaga of Kyoto University (Kyoto, Japan). The cells were maintained as an adherent monolayer culture in RPMI-1640 medium (Invitrogen; Thermo Fisher Scientific, Inc., Waltham, MA, USA) supplemented with $10 \%$ heat-inactivated fetal bovine serum (FBS; Nichirei Biosciences Inc., Tokyo, Japan) and antibiotics $(5 \mathrm{mg} / \mathrm{ml}$ penicillin, $5 \mathrm{mg} / \mathrm{ml}$ streptomycin and $10 \mathrm{mg} / \mathrm{ml}$ neomycin; Invitrogen; Thermo Fisher Scientific, Inc.) in an atmosphere containing $5 \% \mathrm{CO}_{2}$ at $37^{\circ} \mathrm{C}$. All subsequent incubations were also performed at $37^{\circ} \mathrm{C}$. 
The cells were harvested from near-confluent cultures by brief exposure to a solution containing $0.25 \%$ trypsin and $1 \mathrm{mmol} / \mathrm{l}$ ethylenediaminetetraacetic acid (tetrasodium salt) solution with phenol red (Invitrogen; Thermo Fisher Scientific, Inc.). Trypsinization was stopped using RPMI-1640 containing $10 \%$ FBS. The cells were concentrated via centrifugation at $300 \mathrm{x} \mathrm{g}$ for $5 \mathrm{~min}$ at room temperature and resuspended in RPMI-1640. The cell suspension was mixed at $1: 1$ with $0.4 \%$ Trypan blue at room temperature and immediately loaded into the counting chamber slide (Watson Bio Lab; Fukae-Kasei Co., Ltd., Kobe, Japan). Within 5 min, the Trypan blue exclusion assay was performed to assess cell viability using an inverted microscope (Nikon Eclipse TS100; Nikon Corporation, Tokyo, Japan) at a magnification of $\mathrm{x} 100$.

Chemicals. MitoTracker Green FM and LysoTracker Yellow HCK-123 were obtained from Thermo Fisher Scientific Inc. Cell Counting Kit- 8 and the PromoKine Apoptotic/Necrotic Cells Detection kit were purchased from Dojindo Molecular Technologies, Inc., (Kumamoto, Japan) and PromoCell GmbH (Heidelberg, Germany), respectively. The Muse ${ }^{\circledR}$ Oxidative Stress kit and the Muse Annexin V and Dead Cell assay kit were purchased from EMD Millipore (Billerica, MA, USA).

Subcellular localization of TONS504. The intracellular distribution of TONS504 was monitored using an Olympus Fluoview FV1000 (Olympus Corporation, Tokyo, Japan) confocal laser scanning microscope (CLSM). The EMT6 cells were seeded in 8-well cell culture slides (SPL Life Sciences, Pocheon, Korea) and incubated in RPMI-1640 medium for $24 \mathrm{~h}$ at $37^{\circ} \mathrm{C}$. Following this, the cells were incubated with TONS504 at a final concentration of $30 \mu \mathrm{g} / \mathrm{ml}$ for $4 \mathrm{~h}$, followed by co-incubation with $100 \mathrm{nM}$ MitoTracker Green FM and $50 \mathrm{nM}$ LysoTracker Yellow HCK-123 for an additional $30 \mathrm{~min}$ in the culture medium prior to a CLSM being used. The fluorescence of TONS504 was detected at an excitation wavelength of $543 \mathrm{~nm}$ using a helium-neon $(\mathrm{G})$ laser and a 560-nm long-pass filter. The fluorescent signals of MitoTracker Green FM and LysoTracker Yellow HCK-123 were detected by excitation at $488 \mathrm{~nm}$ using an argon laser, a $560 \mathrm{~nm}$ dichroic mirror and a 505-525 $\mathrm{nm}$ band-pass barrier filter.

Uptake kinetics of TONS504. The EMT6 cells were seeded at $1-2 \times 10^{4}$ cells/well in 96-well plates (Corning Incorporated, Corning, NY, USA) in RPMI-1640 medium supplemented with $10 \% \mathrm{FBS}$ and incubated for $24 \mathrm{~h}$ in an atmosphere of 5\% $\mathrm{CO}_{2}$ at $37^{\circ} \mathrm{C}$. Next, the cells were incubated with TONS504 at a final concentration of $30 \mu \mathrm{g} / \mathrm{ml}$ for $12 \mathrm{~h}$ at $37^{\circ} \mathrm{C}$. Images were automatically captured every $1 \mathrm{~h}$ for $12 \mathrm{~h}$ using the IncuCyte ${ }^{\circledR}$ S3 system (Essen BioScience, Ann Arbor, MI, USA) in phase-contrast and fluorescence modes. Phase contrast and red-phase images were obtained from the system. The total fluorescence intensity of objects in an image was determined by object counting using the image analysis software IncuCyte (IncuCyte ${ }^{\circledR}$ S3 Software; Essen Bioscience, Ann Arbor, MI, USA).

Evaluation of the cytotoxic effects of TONS504 and light in EMT6 cells. EMT6 cells were seeded at $1-2 \times 10^{4}$ cells/well in 96-well plates (Corning Incorporated) and incubated for
$24 \mathrm{~h}$. The cells were then incubated with various concentrations of TONS504 $(0,1,3,10,30$ or $100 \mu \mathrm{g} / \mathrm{ml})$ for $24 \mathrm{~h}$ at $37^{\circ} \mathrm{C}$. Following replacing with fresh RPMI-1640 medium supplemented with $10 \%$ FBS, the cells were irradiated by a semiconductor laser at a wavelength of $677 \mathrm{~nm}$. PDT was performed at $11 \mathrm{~mW} / \mathrm{cm}^{2}$ in cells exposed to TONS504 $(0,1,3$, $10,30$ or $100 \mu \mathrm{g} / \mathrm{ml})$, using four light doses $\left(0,1,5\right.$ or $\left.10 \mathrm{~J} / \mathrm{cm}^{2}\right)$. The cells were then incubated for $24 \mathrm{~h}$ in the dark prior to assessing their viability using a WST8 assay (Cell Counting Kit-8; Dojindo Molecular Technologies, Inc.), according to the manufacturer's protocols. The cytotoxic effects of PDT were evaluated to calculate the appropriate concentration of TONS504 and light dose for the following experiment. The concentrations of TONS504 or light doses that were too low were ineffective; however, the concentrations of TONS504 or light doses that were too high were too effective. The optimal concentrations of TONS504 and light dose were $10 \mu \mathrm{g} / \mathrm{ml}$ and $5 \mathrm{~J} / \mathrm{cm}^{2}$ respectively, which results in the best cytotoxic effect.

Kinetics experiment to assess apoptosis. EMT6 cells were seeded at $1-2 \times 10^{4}$ cells/well in 96 -well plates (Corning Incorporated) and incubated for $24 \mathrm{~h}$. The cells were then incubated with various concentrations of TONS504 (0, 1, 3, 10, 30 or $100 \mu \mathrm{g} / \mathrm{ml}$ ) for $24 \mathrm{~h}$ at $37^{\circ} \mathrm{C}$. Following replacing with fresh RPMI-1640 medium supplemented with $10 \%$ FBS, the cells were irradiated with $677-\mathrm{nm}$ light emitted by a semiconductor laser. PDT was performed at $5 \mathrm{~J} / \mathrm{cm}^{2}$, which was determined as optimal light dose by taking into consideration the results of the cytotoxicity effects of TONS504 and light on EMT6 cells. Then, the cells were stained with Annexin V-FITC immediately following PDT and incubated in an atmosphere containing $5 \% \mathrm{CO}_{2}$ at $37^{\circ} \mathrm{C}$ for $24 \mathrm{~h}$. Images were automatically captured every $1 \mathrm{~h}$ for $24 \mathrm{~h}$ in phase-contrast and fluorescence modes using the IncuCyte S3 system. Phase contrast and green-phase images were obtained from the system. The Total Green Object Integrated Intensity in an image was determined by object counting with IncuCyte ${ }^{\circledR}$ S3 Software according to the manufacturer's protocol. In the present study, object counting means the total sum of intensity of Annexin V Green fluorescence in the image.

Analysis of cell death. EMT6 cells were seeded at $4-5 \times 10^{4}$ cells/well in $35-\mathrm{mm}$ petri dishes (Nalge Nunc International, Penfield, NY, USA) containing $2 \mathrm{ml}$ RPMI-1640 medium supplemented with $10 \%$ FBS. Following $24 \mathrm{~h}$ of incubation, the cells were divided into the TONS504 groups (treated with 10 or $30 \mu \mathrm{g} / \mathrm{ml}$ TONS504) and the PDT groups (treated with 10 or $30 \mu \mathrm{g} / \mathrm{ml}$ TONS504 and then irradiated with a light dose of 1,5 or $10 \mathrm{~J} / \mathrm{cm}^{2}$ ). The concentration of used TONS504 was selected by taking into consideration the results of the cytotoxicity effects of TONS504 and light on EMT6 cells.

The cells were incubated with 10 or $30 \mu \mathrm{g} / \mathrm{ml}$ TONS504 for $24 \mathrm{~h}$. Following washing with fresh media, the cells were irradiated with a laser light of wavelength $677 \mathrm{~nm}$ $\left(11 \mathrm{~mW} / \mathrm{cm}^{2}\right.$; $0,1,5$ or $\left.10 \mathrm{~J} / \mathrm{cm}^{2}\right)$. Following $24 \mathrm{~h}$ of PDT, the cells were stained using the PromoKine Apoptotic/Necrotic Cells Detection kit, according to the manufacturer's protocols. To assess apoptosis and necrosis, the cells were stained with Annexin V-fluorescein isothiocyanate (FITC) and ethidium homodimer III (EthD-III) at $24 \mathrm{~h}$ after laser irradiation. Cell 
morphology was examined using a CLSM. The cells were analyzed by fluorescence microscopy using an FITC and Texas Red filter set.

Analysis of apoptosis and reactive oxygen species (ROS) generation. EMT6 cells were seeded at $4-5 \times 10^{4}$ cells/well in $35-\mathrm{mm}$ petri dishes containing $2 \mathrm{ml}$ culture medium. Following $24 \mathrm{~h}$ of incubation, the cells were divided into the following groups: Control (no treatment); laser (irradiated with a light dose of $10 \mathrm{~J} / \mathrm{cm}^{2}$ ); TONS504 (treated with 10 or $30 \mu \mathrm{g} / \mathrm{ml}$ TONS504); and PDT (treated with 10 or $30 \mu \mathrm{g} / \mathrm{ml}$ TONS504, and then irradiated with a light dose of 1,5 or $10 \mathrm{~J} / \mathrm{cm}^{2}$ ). Following this, the cells were incubated with 10 or $30 \mu \mathrm{g} / \mathrm{ml}$ TONS504 for $24 \mathrm{~h}$.

Apoptosis. Following the treatment with 10 or $30 \mu \mathrm{g} / \mathrm{ml}$ TONS504, the cells were washed with fresh media and irradiated with $677-\mathrm{nm}$ light $\left(1,5\right.$ or $\left.10 \mathrm{~J} / \mathrm{cm}^{2}\right)$. Apoptosis was assessed at $24 \mathrm{~h}$ after laser irradiation using the Muse Annexin $\mathrm{V}$ and Dead Cell Assay kit, according to the manufacturer's protocols. Annexin V was used to detect phosphatidylserine on the external membrane of apoptotic cells.

ROS assay. Following treatment with 10 or $30 \mu \mathrm{g} / \mathrm{ml} \mathrm{TONS504,}$ the cells were washed with fresh media and irradiated with 677 -nm light $\left(1,5\right.$ or $\left.10 \mathrm{~J} / \mathrm{cm}^{2}\right)$. ROS generation was assessed at $24 \mathrm{~h}$ after laser irradiation using the Muse Oxidative Stress kit, according to the manufacturer's protocols. The kit was used to determine the percentages of cells that were ROS(-) (healthy cells) and $\operatorname{ROS}(+)$.

Statistical analysis. Data were analyzed using Sidak's multiple comparison test following two-way analysis of variance. $\mathrm{P}<0.05$ was considered to indicate a statistically significant difference. Statistical analyses were performed using GraphPad Prism version 6 (GraphPad Software Inc., La Jolla, CA, USA). Results are presented as the mean \pm standard deviation $(n=3)$.

\section{Results}

Subcellular localization of TONS504. Confocal micrographs of EMT6 cells exposed to TONS504 and fluorescent molecular probes are depicted in Fig. 2. TONS504 was mainly localized in the lysosomes and partially localized in the mitochondria. No fluorescence was detected in the nuclei.

Uptake kinetics of TONS504. The uptake of TONS504 was investigated by studying its fluorescence emission using a live-cell analysis system. It was observed that fluorescence intensity increased slowly within $5 \mathrm{~h}$, followed by a rapid increase up to $8 \mathrm{~h}$ post-incubation. Fluorescence reached a plateau at $10 \mathrm{~h}$ (Fig. 3).

TONS504- and light-induced cytotoxicities to EMT6 cells. The viability of EMT6 cells at $24 \mathrm{~h}$ post-PDT is illustrated in Fig. 4. Cell survival was dependent on TONS504 concentration or light dose, and was demonstrated to be markedly lower at high TONS504 concentrations compared with that at lower concentrations. No cytotoxicity was observed in cells treated with $0 \mathrm{~J} / \mathrm{cm}^{2}$ of light. At $1 \mu \mathrm{g} / \mathrm{ml}$ TONS504, the cell

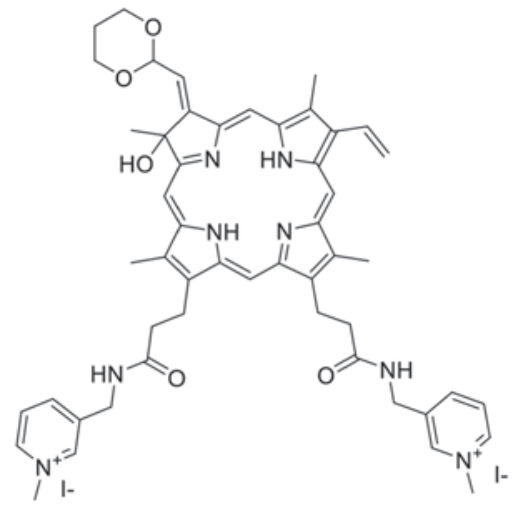

Figure 1. Chemical structure of TONS504.

viability in $1 \mathrm{~J} / \mathrm{cm}^{2}$ of light was significantly lower compared with that in $0 \mathrm{~J} / \mathrm{cm}^{2}$ of light $(\mathrm{P}=0.0046)$. Additionally, the cell viability in $5 \mathrm{~J} / \mathrm{cm}^{2}$ of light was significantly lower compared with that in $1 \mathrm{~J} / \mathrm{cm}^{2}$ of light $(\mathrm{P}<0.0001)$. Furthermore, the cell viability in $10 \mathrm{~J} / \mathrm{cm}^{2}$ of light was significantly lower compared with that in $1 \mathrm{~J} / \mathrm{cm}^{2}$ of light ( $\left.\mathrm{P}=0.029\right)$. At $3 \mu \mathrm{g} / \mathrm{ml}$ TONS504, the cell viability in $5 \mathrm{~J} / \mathrm{cm}^{2}$ of light was significantly lower compared with that in 0 and $1 \mathrm{~J} / \mathrm{cm}^{2}$ of light (both $\mathrm{P}<0.0001$ ), and the cell viability in $10 \mathrm{~J} / \mathrm{cm}^{2}$ of light was significantly lower compared with that in 0,1 and $5 \mathrm{~J} / \mathrm{cm}^{2}$ of light (all $\mathrm{P}<0.0001$ ). At $10 \mu \mathrm{g} / \mathrm{ml}$ TONS504, the cell viability in $5 \mathrm{~J} / \mathrm{cm}^{2}$ of light was significantly lower compared with that in 0 and $1 \mathrm{~J} / \mathrm{cm}^{2}$ of light (both $\mathrm{P}<0.0001$ ), and the cell viability in $10 \mathrm{~J} / \mathrm{cm}^{2}$ of light was significantly lower compared with that in 0,1 and $5 \mathrm{~J} / \mathrm{cm}^{2}$ of light (all $\mathrm{P}<0.0001$ ). At $30 \mu \mathrm{g} / \mathrm{ml}$ TONS504, the cell viability in $5 \mathrm{~J} / \mathrm{cm}^{2}$ of light was significantly lower compared with that in 0 and $1 \mathrm{~J} / \mathrm{cm}^{2}$ of light (both $\mathrm{P}<0.0001$ ), and the cell viability in $10 \mathrm{~J} / \mathrm{cm}^{2}$ of light was significantly lower compared with that in 0 and $1 \mathrm{~J} / \mathrm{cm}^{2}$ of light (both $\mathrm{P}<0.0001$ ). At $100 \mu \mathrm{g} / \mathrm{ml}$ TONS504, the cell viability in $1 \mathrm{~J} / \mathrm{cm}^{2}$ of light was significantly lower compared with that in $0 \mathrm{~J} / \mathrm{cm}^{2}$ of light $(\mathrm{P}<0.0001)$. The cell viability in $5 \mathrm{~J} / \mathrm{cm}^{2}$ of light was significantly lower compared with that in 0 and $1 \mathrm{~J} / \mathrm{cm}^{2}$ of light (both $\mathrm{P}<0.0001$ ), and the cell viability in $10 \mathrm{~J} / \mathrm{cm}^{2}$ of light was significantly lower compared with that in 0 and $1 \mathrm{~J} / \mathrm{cm}^{2}$ of light (both $\mathrm{P}<0.0001$ ).

The half maximal inhibitory concentration $\left(\mathrm{IC}_{50}\right)$ was determined. It was determined that the $\mathrm{IC}_{50}$ values of TONS504 against EMT6 cells exposed to light doses of 5 and $10 \mathrm{~J} / \mathrm{cm}^{2}$ were 5.9 and $1.9 \mu \mathrm{g} / \mathrm{ml}$, respectively.

Kinetics experiment to assess apoptosis. Apoptosis induced by TONS504-mediated PDT was determined by Annexin V-FITC fluorescence using a live-cell analysis system. Apoptosis was dependent on the concentration of TONS504 (Fig. 5). At a low TONS504 concentration $(<10 \mu \mathrm{g} / \mathrm{ml})$, apoptosis occurred from $\sim 10 \mathrm{~h}$ after PDT; however, treatment with $30 \mu \mathrm{g} / \mathrm{ml}$ TONS504 (middle dose) resulted in apoptosis induction at 1-3 $\mathrm{h}$ after PDT. Furthermore, when TONS504 was used at a high dose $(100 \mu \mathrm{g} / \mathrm{ml})$, apoptosis occurred immediately after PDT. The Total Green Object Integrated Intensity [green calibrated unit (GCU) $\mathrm{x} \mu \mathrm{m}^{2} /$ image] in $3 \mu \mathrm{g} / \mathrm{ml}$ TONS504 was significantly higher compared with that in $0 \mu \mathrm{g} / \mathrm{ml}$ TONS504 $(\mathrm{P}=0.0459)$. The GCU in $10 \mu \mathrm{g} / \mathrm{ml}$ TONS504 was significantly higher 

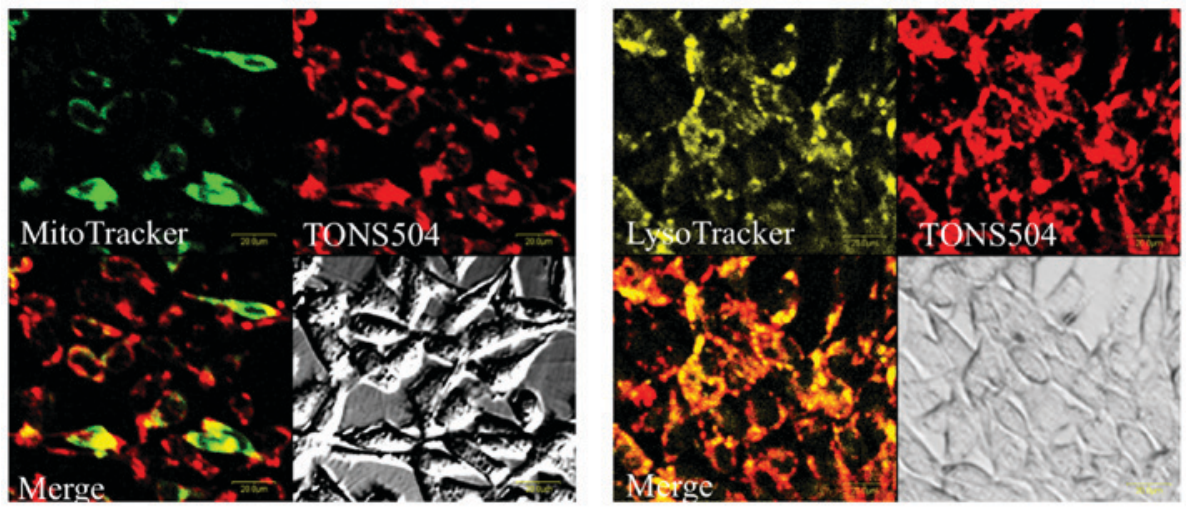

Figure 2. Subcellular localization of TONS504. The subcellular localization of TONS504 was characterized by confocal laser scanning microscopy. The images depict that TONS504 was localized mainly in the lysosomes and partially in the mitochondria. Scale bar, $20 \mu \mathrm{m}$.

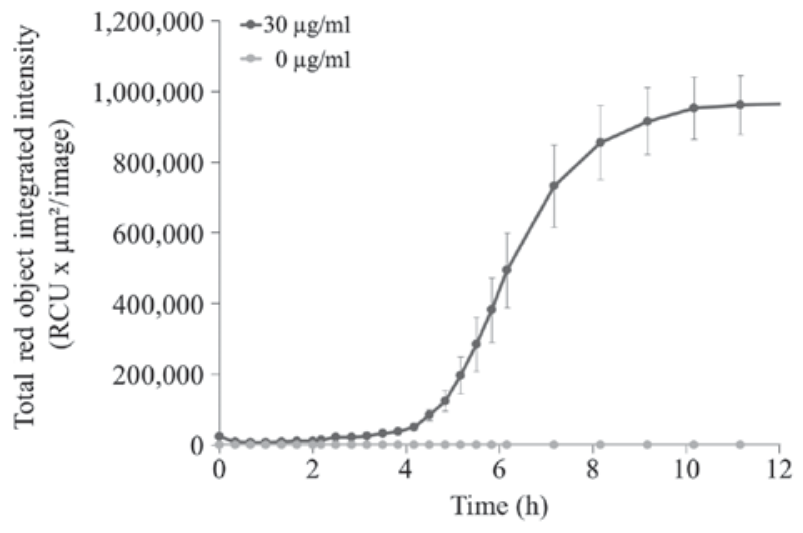

Figure 3. Uptake kinetics of TONS504. The uptake of TONS504 was determined by assessing the fluorescence emission of the drug using a live-cell analysis system. TONS504 uptake was determined from the total fluorescence intensity of the objects in an image. RCU, red calibrated unit.

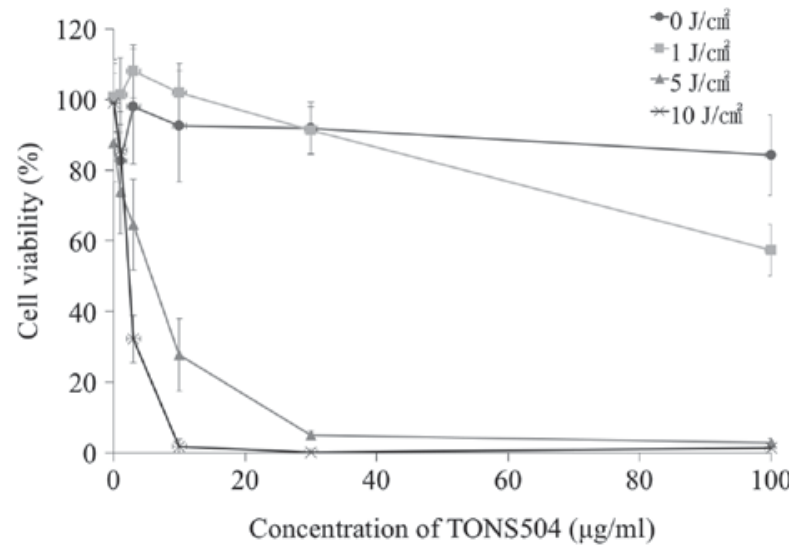

Figure 4. TONS504- and light-induced cytotoxicities to EMT6 cells. The viability of EMT6 cells at $24 \mathrm{~h}$ after photodynamic therapy was determined. In addition, the $\mathrm{IC}_{50}$ was determined. The $\mathrm{IC}_{50}$ values at light doses of 5 and $10 \mathrm{~J} / \mathrm{cm}^{2}$ were 5.9 and $1.9 \mu \mathrm{g} / \mathrm{ml}$, respectively. IC $_{50}$, half maximal inhibitory concentration.

compared with that in 0,1 and $3 \mu \mathrm{g} / \mathrm{ml}$ TONS504 (all $\mathrm{P}<0.0001)$. The GCU in $30 \mu \mathrm{g} / \mathrm{ml}$ TONS504 was significantly higher compared with that in $0,1,3$ and $10 \mu \mathrm{g} / \mathrm{ml}$ TONS504 (all $\mathrm{P}<0.0001$ ). The GCU in $100 \mu \mathrm{g} / \mathrm{ml}$ TONS504

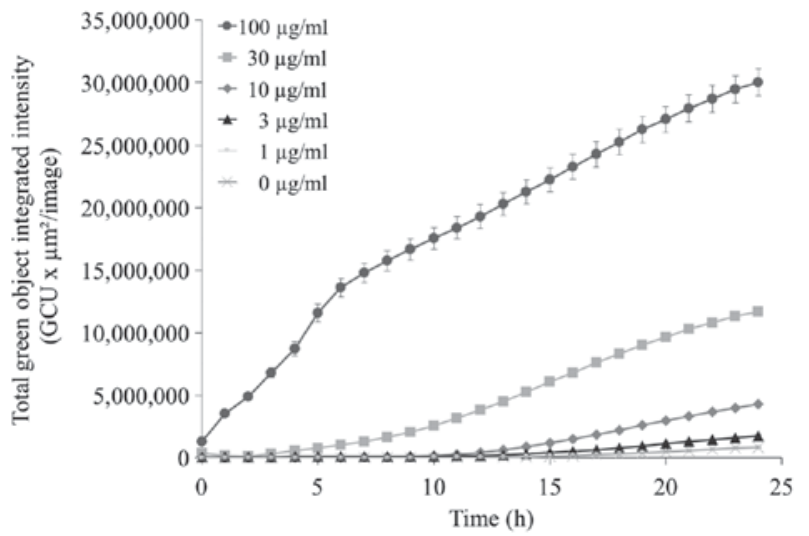

Figure 5. Assessment of apoptosis in the kinetics experiment. Apoptosis induced by TONS504-mediated photodynamic therapy was determined by Annexin V-fluorescein isothiocyanate fluorescence study using a live-cell analysis system. The $\mathrm{x}$-axis represents time in $\mathrm{h}$ and $\mathrm{y}$-axis represents the total green object integrated intensity. TONS504 uptake was determined from the total fluorescence intensity of the objects in an image. GCU, green calibrated unit.

was significantly higher compared with that in $0,1,3,10$ and $30 \mu \mathrm{g} / \mathrm{ml}$ TONS504 (all $\mathrm{P}<0.0001$ ).

Analysis of cell death using a CLSM. The images of EMT6 cells stained with Annexin V-FITC and EthD-III at $24 \mathrm{~h}$ after PDT with $10 \mu \mathrm{g} / \mathrm{ml}$ TONS504 are depicted in Fig. 6. The cells subjected to PDT with $5 \mathrm{~J} / \mathrm{cm}^{2}$ laser energy were stained with EthD-III, which indicated that they were necrotic (Fig. 6C). Furthermore, following PDT with $10 \mathrm{~J} / \mathrm{cm}^{2}$ laser energy, different cells were positively stained with Annexin V or EthD-III, which indicated that they were apoptotic or necrotic (Fig. 6D).

The images of EMT6 cells stained with Annexin V-FITC and EthD-III at $24 \mathrm{~h}$ after PDT with $30 \mu \mathrm{g} / \mathrm{ml}$ TONS504 are depicted in Fig. 7. The cells that were subjected to PDT with $5 \mathrm{~J} / \mathrm{cm}^{2}$ laser energy were stained with Annexin $\mathrm{V}$ and EthD-III, which indicated that they were in either in the late apoptosis or early necrosis stage (Fig. 7C); however, a decrease in the number of EMT6 cells was observed following PDT with $10 \mathrm{~J} / \mathrm{cm}^{2}$ laser energy. In addition, different cells were stained with Annexin V or EthD-III, which indicated that the cells were apoptotic or necrotic (Fig. 7D). 

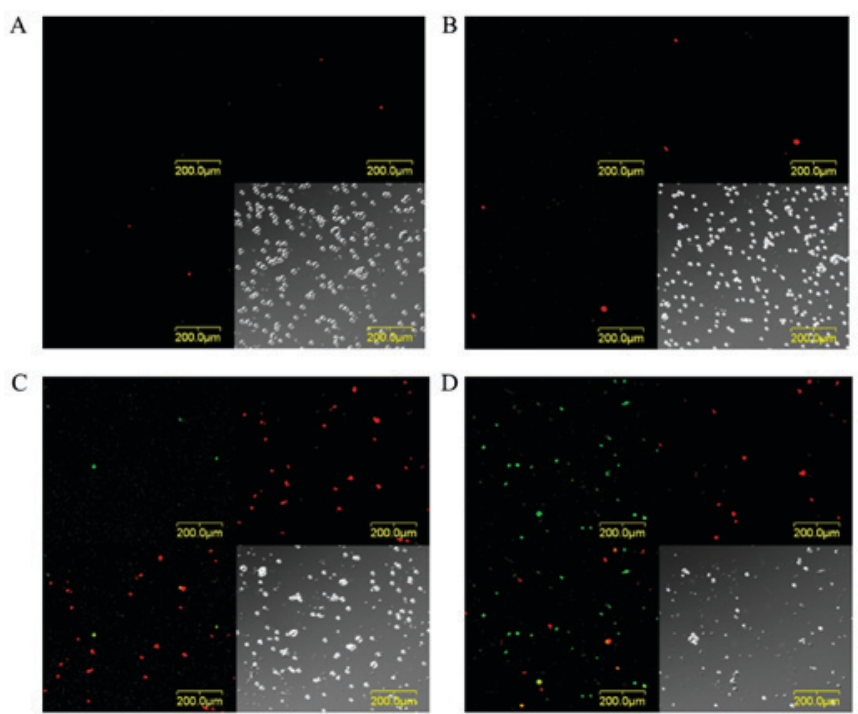

Figure 6. Representative images of EMT6 cells stained with Annexin V-fluorescein isothiocyanate (green) and ethidium homodimer III (red) following PDT. The cells were incubated with $10 \mu \mathrm{g} / \mathrm{ml}$ TONS504 for $24 \mathrm{~h}$. Following washing with fresh medium, the cells were irradiated with $677-\mathrm{nm}$ laser light $\left(11 \mathrm{~mW} / \mathrm{cm}^{2} ; 0,1,5\right.$ or $\left.10 \mathrm{~J} / \mathrm{cm}^{2}\right)$. Following $24 \mathrm{~h}$ of PDT, the cells were stained using the PromoKine Apoptotic/Necrotic Cells Detection kit. The images depict (A) $10 \mu \mathrm{g} / \mathrm{ml}$ TONS504 and $0 \mathrm{~J} / \mathrm{cm}^{2}$ laser energy, (B) $10 \mu \mathrm{g} / \mathrm{ml}$ TONS504 and $1 \mathrm{~J} / \mathrm{cm}^{2}$ laser energy, (C) $10 \mu \mathrm{g} / \mathrm{ml}$ TONS504 and $5 \mathrm{~J} / \mathrm{cm}^{2}$ laser energy, and (D) $10 \mu \mathrm{g} / \mathrm{ml} \mathrm{TONS} 504$ and $10 \mathrm{~J} / \mathrm{cm}^{2}$ laser energy. Scale bar, $200 \mu \mathrm{m}$. PDT, photodynamic therapy.
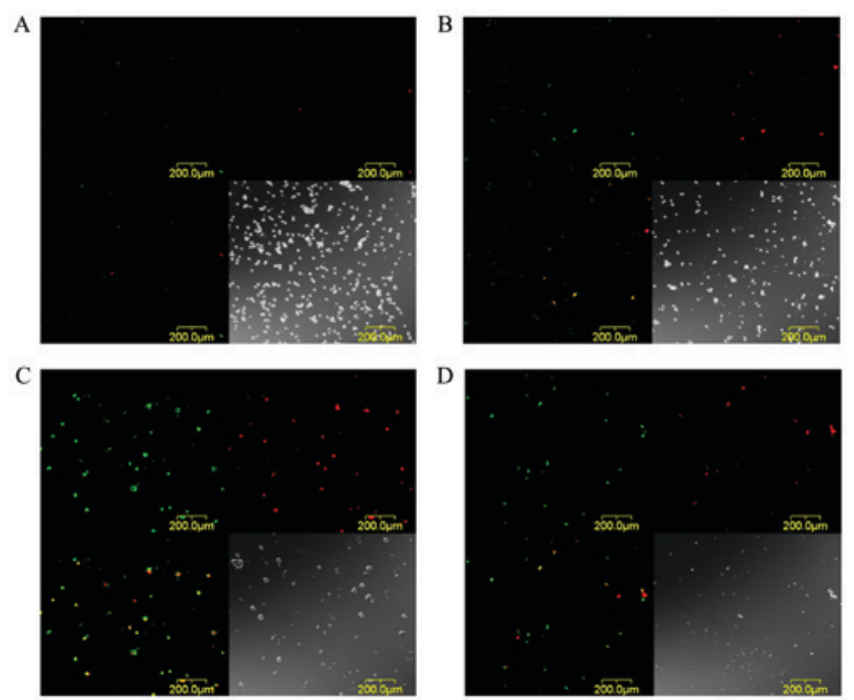

Figure 7. Representative images of EMT6 cells stained with Annexin V-fluorescein isothiocyanate (green) and ethidium homodimer III (red) following PDT. The cells were incubated with $30 \mu \mathrm{g} / \mathrm{ml}$ TONS504 for $24 \mathrm{~h}$. Following washing with fresh medium, the cells were irradiated with $677-\mathrm{nm}$ laser light $\left(11 \mathrm{~mW} / \mathrm{cm}^{2} ; 0,1,5\right.$ or $\left.10 \mathrm{~J} / \mathrm{cm}^{2}\right)$. Following $24 \mathrm{~h}$ of PDT, the cells were stained using the PromoKine Apoptotic/Necrotic Cells Detection kit. The images depict (A) $30 \mu \mathrm{g} / \mathrm{ml}$ TONS504 and $0 \mathrm{~J} / \mathrm{cm}^{2}$ laser energy, (B) $30 \mu \mathrm{g} / \mathrm{ml}$ TONS504 and $1 \mathrm{~J} / \mathrm{cm}^{2}$ laser energy, (C) $30 \mu \mathrm{g} / \mathrm{ml}$ TONS504 and $5 \mathrm{~J} / \mathrm{cm}^{2}$ laser energy, and (D) $30 \mu \mathrm{g} / \mathrm{ml} \mathrm{TONS504}$ and $10 \mathrm{~J} / \mathrm{cm}^{2}$ laser energy. Scale bar, $200 \mu \mathrm{m}$. PDT, photodynamic therapy.

ROS assay. The percentage of $\operatorname{ROS}(+)$ cells at $24 \mathrm{~h}$ after PDT is depicted in Fig. 8. For cells subjected to PDT with $5 \mathrm{~J} / \mathrm{cm}^{2}$ laser energy, the percentage of $\operatorname{ROS}(+)$ cells following treatment with $30 \mu \mathrm{g} / \mathrm{ml}$ TONS504 was significantly higher compared with that of cells treated with $10 \mu \mathrm{g} / \mathrm{ml}$ TONS504 $(\mathrm{P}=0.001)$. By contrast, for cells subjected to PDT with $10 \mathrm{~J} / \mathrm{cm}^{2}$ laser energy, the percentage of ROS(+) cells following treatment with $10 \mu \mathrm{g} / \mathrm{ml}$ TONS504 was significantly higher compared with that of cells treated with $30 \mu \mathrm{g} / \mathrm{ml}$ TONS504 $(\mathrm{P}=0.0048)$. The percentage of ROS(+) cells in the PDT group increased in a light- and dose-dependent manner for each TONS504 dose.

Analysis of apoptosis. At $24 \mathrm{~h}$ after PDT with 1, 5 or $10 \mathrm{~J} / \mathrm{cm}^{2}$ laser energy, the apoptotic rates in groups treated with $10 \mu \mathrm{g} / \mathrm{ml}$ TONS504 were significantly higher compared with those in groups treated with $30 \mu \mathrm{g} / \mathrm{ml}$ TONS504 in the respective groups (all $\mathrm{P}<0.0001$; Fig. 9). Furthermore, the percentage of apoptotic cells following PDT increased in a light- and dose-dependent manner for each TONS504 dose.

\section{Discussion}

In our previous study, CLSM analysis revealed that TONS501Na accumulates in the mitochondria and lysosomes (6). It was also reported that meso-tetra (hydroxyphenyl) chlorin and hypericin exhibit similar uptake kinetics, with a continuous increase in fluorescence within the first $20 \mathrm{~h}$ (11). In the present study, TONS504 accumulated primarily in the lysosomes. In addition, its uptake reached a plateau at $10 \mathrm{~h}$. It was considered that TONS504, being cationic, may strongly interact with the cytomembrane, which possesses a negative charge, and enter the cells rapidly (12); therefore, TONS504 may partially move to the mitochondria following accumulation in the lysosomes.

In our previous study, TONS501Na-mediated PDT-induced cell death in EMT6 cells in a manner dependent on photosensitizer dose and light energy. The $\mathrm{IC}_{50}$ values of TONS501Na against EMT6 cells were 8.2 and $2.2 \mu \mathrm{g} / \mathrm{ml}$ at a laser power of 6 and $13 \mathrm{~J} / \mathrm{cm}^{2}$, respectively (6). In the present study, it was determined that TONS504-mediated PDT-induced EMT6 cell death in a dose-dependent manner. The $\mathrm{IC}_{50}$ values of TONS504 against EMT6 cells were 5.9 and $1.9 \mu \mathrm{g} / \mathrm{ml}$ at light doses of 5 and $10 \mathrm{~J} / \mathrm{cm}^{2}$, respectively. Although the experimental conditions were slightly different between the two studies, the $\mathrm{IC}_{50}$ of TONS504 was similar to that of TONS501Na. In addition, dark cytotoxicity was observed with TONS501Na in our previous study (6); however, this was not observed with TONS504 in the present study. Therefore, TONS504 is a photosensitizer more suitable for tumor therapy than TONS501Na.

Fig. 5 depicted that apoptotic cell death induced by TONS504-mediated PDT increased in a time-dependent manner and was initiated at 1-3 h after PDT. The cells treated with $10 \mu \mathrm{g} / \mathrm{ml} \mathrm{TONS504} \mathrm{and} \mathrm{a} \mathrm{light} \mathrm{dose} \mathrm{of} 5 \mathrm{~J} / \mathrm{cm}^{2}$ were mainly necrotic (Fig. 6C). Furthermore, the cells treated with $30 \mu \mathrm{g} / \mathrm{ml}$ TONS504 and a light dose of $5 \mathrm{~J} / \mathrm{cm}^{2}$ underwent either late apoptosis or early-stage necrosis (Fig. 7C). The percentages of ROS(+) cells and apoptotic cells in the group subjected to TONS504-mediated PDT increased in a light-energy-dependent manner. When the cells were treated with 10 or $30 \mu \mathrm{g} / \mathrm{ml}$ TONS504 and with a light dose of $10 \mathrm{~J} / \mathrm{cm}^{2}$, the percentage of ROS(+) cells treated with $30 \mu \mathrm{g} / \mathrm{ml}$ TONS504 (56.1\%) was lower than that of cells treated with $10 \mu \mathrm{g} / \mathrm{ml} \mathrm{TONS504} \mathrm{(70.1 \% ).} \mathrm{The}$ results demonstrated that PDT with a high dose of TONS504 may result in a rapid decrease in the number of $\operatorname{ROS}(+)$ cells. 


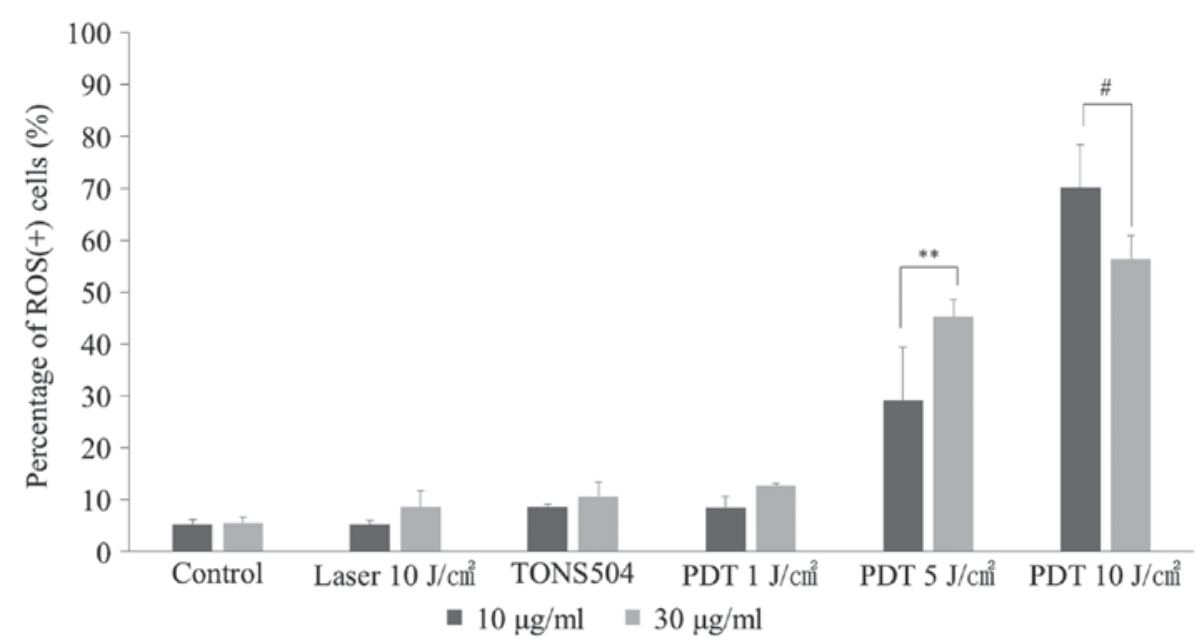

Figure 8. ROS assay. EMT6 cells were incubated with 10 or $30 \mu \mathrm{g} / \mathrm{ml}$ TONS504 for $24 \mathrm{~h}$. Following washing with fresh medium, the cells were irradiated with 677 -nm light $\left(0,1,5\right.$ or $\left.10 \mathrm{~J} / \mathrm{cm}^{2}\right)$. ROS generation was assessed $24 \mathrm{~h}$ after laser irradiation using the Muse ${ }^{\circledR}$ Oxidative Stress kit. Data were analyzed using Sidak's multiple comparison test following two-way analysis of variance. ${ }^{*} \mathrm{P}<0.05$ and ${ }^{* *} \mathrm{P}<0.01$. ROS, reactive oxygen species.

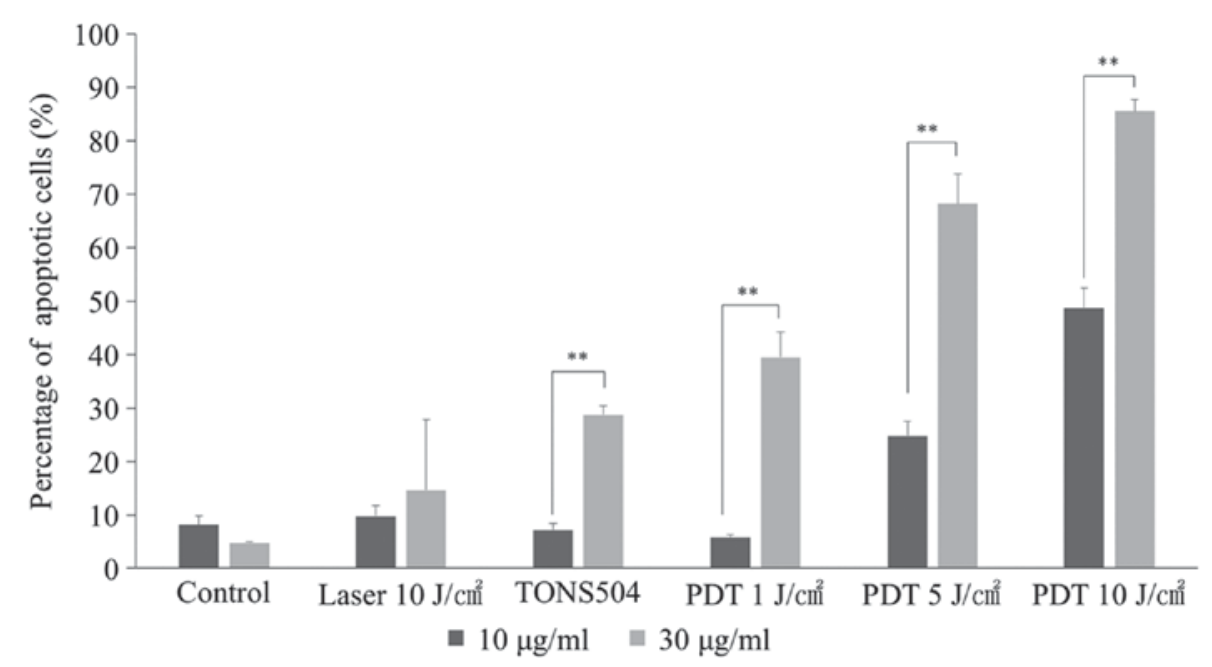

Figure 9. Analysis of apoptosis. EMT6 cells were incubated with 10 or $30 \mu \mathrm{g} / \mathrm{ml}$ TONS504 for $24 \mathrm{~h}$. Following washing with fresh medium, the cells were irradiated with 677-nm light $\left(0,1,5\right.$ or $\left.10 \mathrm{~J} / \mathrm{cm}^{2}\right)$. Apoptosis was assessed $24 \mathrm{~h}$ after laser irradiation using the Muse ${ }^{\circledR}$ Annexin V and Dead Cell Assay kit. Data were analyzed using Sidak's multiple comparison test following two-way analysis of variance. ${ }^{* *} \mathrm{P}<0.01$.

This is due to the notable decrease in cell viability and the rapid induction of apoptosis by TONS504 at a concentration of $30 \mu \mathrm{g} / \mathrm{ml}$. The results also indicated that TONS504-mediated PDT may induce apoptosis, but not ROS-induced damage. It was considered that the differences in cell death induced by TONS504-PDT may be associated with the intracellular accumulation of TONS504, mainly in the lysosomes.

We hypothesized that apoptosis induced by TONS504-mediated PDT may be dependent on lysosomal damage. A previous report indicated that apoptosis induced by ATX-S10-mediated PDT was dependent on lysosomal damage (13). In addition, ATX-S10 was localized to the mitochondria and lysosomes. It has been hypothesized that ATX-S10-mediated PDT initiates an apoptotic response through direct damage to lysosomes. Furthermore, it regulates cell death through photodamage to B-cell lymphoma-2 (Bcl-2) by inducing direct and indirect damage to the mitochondria (13). Talaporfin sodium (NPe6) is also localized in lysosomes. It was reported that following treatment of murine hepatoma 1c1c7 cells with NPe6-PDT, there was a delayed apoptotic response, which was marked by rapid destruction of lysosomes, $\mathrm{BH} 3$-interacting domain death agonist (Bid) cleavage to generate the proapoptotic Bcl-2 family member t-Bid, and activation of caspase-3 and -9. Bid activation decreased mitochondrial membrane potential and cytochrome- $c$ release $(14,15)$. Additionally, photodamaged lysosomes triggered the mitochondrial apoptotic pathway by releasing proteases that activate Bid (14). It was considered that Bid may be activated by high-dose PDT, but not by low-dose PDT. Depending on the extent of photodamage, either apoptosis or necrosis was considered to be initiated; therefore, in the present study, it was considered that apoptosis induced by TONS504-mediated PDT may be dependent on the extent of lysosomal damage, as well as direct and indirect mitochondrial damage. However, these results are only based on in vitro studies, and further in vivo studies are necessary. 
In conclusion, TONS504-mediated PDT induced the death of mouse mammary tumor cells in a manner dependent on the TONS504 dose and light energy. In addition, TONS504 did not induce dark cytotoxicity. Therefore, TONS504 could be an ideal photosensitizer for PDT against tumors. However, future studies are warranted to evaluate the in vivo pharmacokinetics, tissue distribution and photodynamic effects of TONS504 in a mouse model of EMT6 mammary tumors.

\section{Acknowledgements}

The authors would like to thank Mr Shohei Shimonishi (Essen BioScience, Inc., Tokyo, Japan) for providing technical assistance with the experiments.

\section{Funding}

The present study was partly funded by Saisei Mirai Clinic (Osaka, Japan).

\section{Availability of data and materials}

All data generated and analyzed during the present study are included in this published article.

\section{Authors' contributions}

TO, IS and YU conceived, designed, and performed the experiments and wrote the paper. MY, YM, KA, TT, NI, TI and YO interpreted the data and were involved in drafting the manuscript. All authors read and approved the final manuscript.

\section{Ethics approval and consent to participate}

Not applicable.

\section{Consent for publication}

Not applicable.

\section{Competing interests}

The authors declare that they have no competing interests.

\section{References}

1. George BP and Abrahamse H: A review on novel breast cancer therapies: Photodynamic therapy and plant derived agent induced cell death mechanisms. Anticancer Agents Med Chem 16 793-801, 2016
2. Siegel RL, Miller KD and Jemal A: Cancer statistics, 2018. CA Cancer J Clin 68: 7-30, 2018.

3. Banerjee SM, MacRobert AJ, Mosse CA, Periera B, Bown SG and Keshtgar MRS: Photodynamic therapy: Inception to application in breast cancer. Breast 31: 105-113, 2017.

4. Bacellar IO, Tsubone TM, Pavani C and Baptista MS: Photodynamic efficiency: From molecular photochemistry to cell death. Int J Mol Sci 16: 20523-20559, 2015.

5. Triesscheijn M, Baas P, Schellens JH and Stewart FA: Photodynamic therapy in oncology. Oncologist 11: 1034-1044, 2006.

6. Osaki T, Sakata I, Uto Y, Azuma K, Murahata Y, Tsuka T, Itoh N, Imagawa T and Okamoto Y: Photodynamic therapy mediated by a novel chlorin derivative, TONS 501-Na, in EMT6 cells Anticancer Res 37: 1723-1728, 2017.

7. Takahashi H, Nakajima S, Asano R, Nakae Y, Sakata I and Iizuka $\mathrm{H}$ : Photodynamic therapy using a novel photosensitizer, TONS501, is similarly effective to ALA and EC036 photodynamic therapy on DMBA-and TPA-induced mouse skin papilloma. J Dermatol Sci 66: 221-224, 2012.

8. Sakata I: Chlorin derivatives, Japan patent JP5651426 B2. 2015-01-14.

9. Latief MA, Chikama T, Shibasaki M, Sasaki T, Ko JA, Kiuchi Y, Sakaguchi T and Obana A: Antimicrobial action from a novel porphyrin derivative in photodynamic antimicrobial chemotherapy in vitro. Lasers Med Sci 30: 383-387, 2015.

10. Latief MA, Chikama T, Ko JA, Kiuchi Y, Sakaguchi T and Obana A: Inactivation of acyclovir-sensitive and -resistant strains of herpes simplex virus type 1 in vitro by photodynamic antimicrobial chemotherapy. Mol Vis 21: 532-537, 2015.

11. Berlanda J, Kiesslich T, Engelhardt V, Krammer B and Plaetzer K: Comparative in vitro study on the characteristics of different photosensitizers employed in PDT. J Photochem Photobiol B 100: 173-180, 2010.

12. Kou L, Sun J, Zhai y and He Z: The endocytosis and intracellular fate of nanomedicines: Implication for rational design. AJPS 8: $1-10,2013$.

13. Ichinose S, Usuda J, Hirata T, Inoue T, Ohtani K, Maehara S, Kubota M, Imai K, Tsunoda Y, Kuroiwa Y, et al: Lysosomal cathepsin initiates apoptosis, which is regulated by photodamage to $\mathrm{Bcl}-2$ at mitochondria in photodynamic therapy using a novel photosensitizer, ATX-s10 (Na). Int J Oncol 29: 349-355, 2006.

14. Reiners JJ Jr, Caruso JA, Mathieu P, Chelladurai B, Yin XM and Kessel D: Release of cytochrome $\mathrm{c}$ and activation of pro-caspase-9 following lysosomal photodamage involves Bid cleavage. Cell Death Differ 9: 934-944, 2002.

15. Ribeiro JN, da Silva AR and Jorge RA: Involvement of mitochondria in apoptosis of cancer cells induced by photodynamic therapy. J Bras Patol Med Lab 40: 383-390, 2004.

This work is licensed under a Creative Commons Attribution-NonCommercial-NoDerivatives 4.0 International (CC BY-NC-ND 4.0) License. 